\title{
GROWTH PERFORMANCE AND ECONOMIC EFFICIENCY OF FATTENING NAIMI LAMBS ON UNCONVENTIONAL RATION ENHANCED WITH ENZYME COCKTAIL
}

\author{
Mutassim Abdelrahman', Ahmed Sami1, 2,*, Gamaleldin Suliman' ${ }^{1}$ and Alaeldein Abudabos ${ }^{1}$
}

\author{
${ }^{1}$ Department of Animal Production, College of Food and Agriculture Sciences, King Saud University, P.O. Box 2430, \\ Riyadh 11451, Riyadh, Saudi Arabia; ${ }^{2}$ Department of Animal Production, Faculty of Agriculture, Cairo University, \\ 12613, Giza, Egypt. \\ *Corresponding author's e-mail: assami70@yahoo.com
}

\begin{abstract}
The effect of feeding different levels $(0,30$ and 50\%) of crushed date pits (CDP), with or without enzyme cocktail (EC), on the growth performance, blood constituents, and economical efficiency of the growing Naimi lambs was studied. Results of this study showed significantly $(\mathrm{P}<0.05)$ lower final live body weight, total weight gain and higher total feed conversion ratio (TFCR) of lambs fed 50\% CDP without EC when compared with other four groups. Addition of EC to the 50\% CDP improved the performance of the lambs regarding the weight gain, final body weight and TFCR. There were no negative effects of feeding CDP with or without EC in term of monthly and total feed intake. The significant lowest and the highest TFCR values were recorded for the $0 \%$ and 50\% CDP without EC groups, respectively. A significantly higher cholesterol levels were reported for lambs fed CDP without EC compared with other groups. In addition, glucose levels in the blood of lambs fed CDP with or without EC were significantly higher compared with the $0 \% \mathrm{CDP}$, but the opposite trend for the creatinine levels $(\mathrm{P}<0.01)$ was found. In conclusion, up to $50 \%$ of barley can be replaced by crushed date pits with enzyme cocktail in the Naimi lambs ration without any adverse effect on growth performance with almost the same economic efficiency.
\end{abstract}

Keywords: Crushed date pits, enzyme cocktail, lambs, performance, economic efficiency.

\section{INTRODUCTION}

Previous studies reported that date excluded from human consumption could be beneficially used as an ingredient in the diets of small ruminants (Al-Dobaib et al., 2009). Date byproducts were used in animal rations to test the growth performance and products quality as meat and milk by Ziaei (2010) and Alhomidy et al. (2011) and reproductive efficiency by Jumah et al. (1983) and antioxidant status by Habib et al. (2011). Due to the extensive work on date palm byproducts, many and varied contradictive results and conclusions were raised.. On the other hand, other studies suggested that the presence of anti-nutritive factors limit the nutritional potential of date palm leaves (Arhab et al., 2006). Feeding low quality date byproducts feeds containing antinutritional factors for relatively long periods might produce negative effects on the physiology and chemistry of the digestive system and blood parameters, which might negatively affect sheep health and make them more susceptible to diseases (Mahgoub et al., 2008). Taking into account that different treatments were applied to make use of date palm byproducts such as sun-dried (Geelen and Udo, 1964), mechanical grinding of date pits (Jumah et al., 1973) urea treated-palm fronds (Mahgoub et al., 2007), pelleting date leaves (Mahgoub et al., 2008) and chopping low quality dates (Ziaei, 2010). Other treatments such as soaking in water, roasting, mashing and screening were also reported (FAO, 2009). Based on previous studies and their recommendations, more research is needed to explore the real potentialities of date byproducts when treated by new and untraditional methods.

For ruminants, using enzymes is a new concept and many suggestions and assumptions were made to explain their positive or negative effect on their performance. Since most of the agro byproduct contains high fiber and other antinutrients which reduce their digestion and utilization by ruminants and non-ruminant animals, using fibrolytic enzymes can be one of the most proper solutions for these limitations. Various combinations of enzymes are available in the market and have shown very promising results in hydrolyzing plant fibers and anti-nutrients. The mode of action of enzyme occurs by several pre or post-ingestive process (McAllister et al., 2001). Pre-ingestive process, enzymes hydrolyze glycosidic linkages of the polysaccharides in the cell wall and release monosaccharide. For the post-ingestive process, enzyme play an important role in improving feed palatability as a result of breaking the polysaccharides bonds and release monosaccharide and consequently reduce the viscosity (Rode et al., 1999). Furthermore, it stimulates the microbial activities and increases the synergic effect of microbial fibrolytic enzymes and commercial enzyme complex (Morgavi et al., 2000; 
Beauchemin et al., 2003). Adding fibrolytic enzyme increases the rate (Beauchemin et al., 2003) or extent (Krueger et al., 2008) of fiber hydrolysis and digestion, or reduces fiber concentration (Krueger and Adesogan, 2006). This leads to influence the acetate to propionate ratio in the rumen fluid and consequently type of energy available for animal productivity. For protein, adding fibrloytic enzymes affect the proteolysis rate and methane production, but findings are inconsistent regarding this matter. More research is required to provide more accurate, consistent and a significant economical attractive improvement in livestock productivity by using enzymes.

The objective of this study was to investigate the effect of including crushed date pits (CDP), with or without enzyme cocktail (EC) on the growth performance, blood constituents and economics in Naimi lambs.

\section{MATERIALS AND METHODS}

Treatments: This experiment was conducted at the experimental farm of the animal production department, college of food and agriculture sciences, King Saud University, Saudi Arabia from January to March, 2014. Twenty-five three months old Naimi lambs, initially weighed $24.53 \pm 0.40 \mathrm{~kg}$, were used in this fattening trial. They were randomly distributed equally into five groups and each housed in an individual pen $(0.8 \times 1.4 \mathrm{~m})$ with separate feeder and drinker. Crushed date pits (CDP) with or without a commercial enzyme mixture (Enzyme cocktail, EC) supplementation (Tomoko, a commercial enzyme mixture supplement that contains acidic protease, $\alpha$-amylase, pectinase, phytase, glucoamylase, cellulose and Aspergillus
Awamori cells) were partially replaced the barley in the lamb's ration. The dietary treatments for each group were as follows: Control; T1 (30\% of CDP); T2 (30\% of CDP plus EC); T3 (50\% of CDP); and T4 (50\% of CDP plus EC). The ingredients and chemical composition of the total mixed rations of the experimental groups were formulated according to NRC (1985), to cover all nutrient requirements to be isocaloric and isonitrognous for the five groups (Table 1). One $\mathrm{kg}$ per ton was the level of enzyme added to T2 and T4 groups. Moreover, lambs were fed the assigned rations for two weeks as adaptation period and followed by three months experimental period. Lambs were weighted at the beginning of the experiment and biweekly after overnight fasting. Monthly and total feed conversion ratios were calculated. Blood samples were collected from all lambs at the beginning of the experiment and every 4 weeks via the jugular vein. Blood samples were centrifuged at $3000 \mathrm{rpm}$ for 15 minutes and serum was separated (AOAC, 1996) and stored at $-20^{\circ} \mathrm{C}$ until analysis of different metabolites (Glucose, creatinine cholesterol, HDL, urea N, albumin and total protein) using commercial kits.

Statistical analysis: Data were analyzed by using SAS (2009) as a complete randomized design (CRD). The protected least significant differences (LSD) test was used to determine differences among treatments means for significant dietary effect with $\mathrm{P}<0.05$ considered statistically significant unless otherwise noted.

\section{RESULTS}

Growth performance: There were significant lower final live body weights of lambs fed $50 \%$ crushed date pits (CDP)

Table 1. Ingredients and chemical composition of the trial rations

\begin{tabular}{lccccc}
\hline Ingredient, \% & Control & 30\% CDP* & 30\% CDP + EC & 50\% CDP & 50\% CDP + EC \\
\hline Barley grain & 78.00 & 54.60 & 54.60 & 39.00 & 39.00 \\
Date pits & 0.00 & 23.40 & 23.40 & 39.00 & 39.00 \\
SBM $^{* * *}$ & 8.50 & 8.50 & 8.50 & 8.50 & 8.50 \\
Wheat bran & 11.60 & 11.60 & 11.60 & 11.60 & 11.60 \\
Urea & 0.00 & 0.30 & 0.30 & 0.50 & 0.50 \\
CaCO $_{3}$ & 1.20 & 1.00 & 1.00 & 0.80 & 0.80 \\
Salt & 0.50 & 0.50 & 0.50 & 0.50 & 0.50 \\
Min.+Vit. ${ }^{* * * *}$ & $0.1-0.2$ & $0.1-0.2$ & $0.1-0.2$ & $0.1-0.2$ & $0.1-0.2$ \\
EC & - & - & One kg /tone & - & One kg /tone \\
Chemical composition & & & & & \\
Dry matter\% & 88.50 & 89.90 & 89.90 & 90.10 & 90.10 \\
Crude protein\% & 14.80 & 14.91 & 14.91 & 14.75 & 14.75 \\
Gross energy & 2640.00 & 2652.00 & 2652.00 & 2590.00 & 2590.00 \\
Calcium & 5.44 & 4.61 & 4.61 & 5.79 & 5.79 \\
Phosphorus & 4.78 & 4.75 & 4.75 & 4.50 & 4.50 \\
\hline
\end{tabular}

${ }^{*}$ CDP: Crushed Date Pits, replaced instead of barely by $30 \%$ and $50 \%,{ }^{* *}$ EC: Enzyme cocktail (commercial enzyme mixture): Tomoko, a commercial enzyme mixture supplement that contains acidic protease, $\alpha$-amylase, pectinase, phytase, glucoamylase, cellulose and Aspergillus Awamori cells, ${ }^{* * *}$ SBM: Soya bean meal, ${ }^{* * * *}$ Contained per kg, $10000 \mathrm{IU}$ vitamin A, 1000 IU vitamin D, 20 IU vitamin E, $300 \mathrm{mgMg}, 24 \mathrm{mg} \mathrm{Cu}, 0.6 \mathrm{mg}$ Co, $1.2 \mathrm{mg} \mathrm{I}, 60 \mathrm{mg} \mathrm{Mn}, 0.3 \mathrm{mg} \mathrm{Se}, 60 \mathrm{mg} \mathrm{Zn}$. 
without enzyme cocktail (EC) when compared with other four groups as shown in Table 2. The same trend was found for the total weight gain (Table 3).

Table 2. The effect of feeding crushed date pits (CDP) with or without enzyme cocktail (EC) on monthly live body weight of growing Naimi lambs

\begin{tabular}{lcccc}
\hline Treatments & $\begin{array}{c}\text { Initial } \\
\text { wt.(Kg) }\end{array}$ & $\begin{array}{c}\mathbf{1}^{\text {st }} \text { month } \\
\text { wt. }(\mathbf{K g})\end{array}$ & $\begin{array}{c}\mathbf{2}^{\text {nd }} \text { month } \\
\text { wt. }(\mathbf{g})\end{array}$ & $\mathbf{3}^{\text {rd }}$ wt.(Kg) \\
\hline Control & 23.70 & 28.54 & 35.82 & $43.34^{\mathrm{b}}$ \\
30\%CDP (T1) & 24.55 & 28.89 & 35.98 & $42.66^{\mathrm{b}}$ \\
30\%CDP & 24.38 & 29.11 & 36.24 & $43.06^{\mathrm{b}}$ \\
+ EC (T2) & & 28.80 & 36.08 & $41.50^{\mathrm{a}}$ \\
50\%CDP (T3) & 25.40 & 28.59 & 36.39 & $42.98^{\mathrm{b}}$ \\
50\%CDP & 24.64 & 0.39 & 0.44 & 0.58 \\
+ EC (T4) & 0.40 & 0.98 & 0.88 & 0.05 \\
SEM & 0.99 & 0.98 \\
P value & \multicolumn{5}{l}{} \\
a, b Means on the same column having different letters differ \\
significantly
\end{tabular}

Table 3. The effect of feeding crushed date pits (CDP) with or without Enzyme cocktail (EC) on monthly weight gain $(\mathrm{kg})$ of growing Naimi lambs

\begin{tabular}{lcccc}
\hline Treatments & M*1 & M2 & M3 & TWG $^{* *}$ \\
\hline Control & 4.83 & 7.29 & 7.52 & $19.62^{\mathrm{c}}$ \\
30\%CDP (T1) & 4.34 & 7.08 & 6.40 & $17.82^{\mathrm{a}}$ \\
30\%CDP+ EC (T2) & 4.73 & 7.13 & 6.82 & $18.68^{\mathrm{b}}$ \\
50\%CDP (T3) & 3.40 & 7.28 & 5.43 & $16.10^{\mathrm{a}}$ \\
50\%CDP+ EC (T4) & 4.10 & 7.60 & 6.59 & $18.33^{\mathrm{b}}$ \\
SEM & 0.28 & 0.28 & 0.45 & 0.46 \\
P value & 0.53 & 0.99 & 0.71 & 0.05 \\
\hline
\end{tabular}

*Month, **Total, Weight Gain (kg), ${ }^{\text {a, b }}$ Means on the same column having different letters differ significantly

Adding enzyme to rations contained CDP resulted in improved growth performance when compared with group fed CDP without EC. For the total feed conversion ratio (TFCR), the control group showed a significantly lower TFCR value compared with the other groups, the higher TFCR value was recorded for the lambs from group fed $50 \%$
CDP without EC as presented in Table 4. Furthermore, there were no significant differences between groups in term of monthly and total feed intake (Table 5).

Table 4. The effect of feeding crushed date pits (CDP) with or without enzyme cocktail (EC) on monthly feed conversion ratio (FCR) and total of feed conversion ratio (TFCR) growing Naimi lambs

\begin{tabular}{lcccc}
\hline Treatments & FCR 1 & FCR 2 & FCR 3 & TFCR \\
\hline Control & 6.20 & 5.47 & 6.30 & $5.78^{\mathrm{a}}$ \\
30\%CDP (T1) & 7.56 & 5.46 & 7.44 & $6.29^{\mathrm{b}}$ \\
30\%CDP+ EC (T2) & 7.00 & 5.38 & 7.20 & $6.15^{\mathrm{b}}$ \\
50\%CDP (T3) & 9.58 & 5.44 & 7.80 & $7.00^{\mathrm{c}}$ \\
50\%CDP+ EC (T4) & 7.14 & 5.07 & 7.12 & $6.11^{\mathrm{b}}$ \\
SEM & 0.62 & 0.18 & 0.92 & 0.15 \\
P value & 0.51 & 0.96 & 0.44 & 0.05 \\
\hline
\end{tabular}

$\overline{a, b, c}$ Means on the same column having different letters differ significantly.

Table 5. The effect of feeding crushed date pits (CDP) with or without enzyme cocktail (EC) on monthly and total feed intake of growing Naimi lambs

\begin{tabular}{lrrrr}
\hline Treatments & M1FI* & M2FI & M3FI & TFI** \\
\hline Control & 28.40 & 37.59 & 45.56 & 111.50 \\
30\%CDP (T1) & 28.25 & 38.40 & 45.40 & 112.31 \\
30\%CDP+ EC (T2) & 28.55 & 38.09 & 45.75 & 112.35 \\
$50 \%$ CDP (T3) & 28.76 & 37.75 & 45.71 & 112.22 \\
$50 \%$ CDP+ EC (T4) & 28.19 & 37.70 & 45.79 & 111.66 \\
SEM & 0.14 & 0.13 & 0.03 & 0.23 \\
P value & 0.74 & 0.25 & 0.54 & 0.75 \\
\hline
\end{tabular}

*M1,2,3 FI: Monthly Feed Intake, **TFI: Total Feed Intake

Blood serum metabolites: Significant differences were detected for high density lipoprotein (HDL) and urea- $\mathrm{N}$ at the beginning of the experiment as summarized in Table 6 . At the end of the trial, a significantly higher cholesterol levels were reported for lambs fed CDP without EC compared with other groups (Table 7). In addition, glucose levels in the blood serum of lambs fed CDP with or without EC were significantly higher compared with the control, but the opposite trend for the creatinine levels was observed.

Table 6. Levels of blood serum metabolites at the beginning of the experiment

\begin{tabular}{lccccccc}
\hline Treatment & $\begin{array}{c}\text { Glucose } \\
\text { mg/dl }\end{array}$ & $\begin{array}{c}\text { Total } \\
\text { protein g/dl }\end{array}$ & $\begin{array}{c}\text { Albumin } \\
\text { g/dl }\end{array}$ & $\begin{array}{c}\text { Cholesterols } \\
\text { mg/dl }\end{array}$ & $\begin{array}{c}\text { HDL } \\
\text { g/dl }\end{array}$ & $\begin{array}{c}\text { Creatinine } \\
\text { mg/dl }\end{array}$ & $\begin{array}{c}\text { Urea-N } \\
\text { mg/dl }\end{array}$ \\
\hline Control & 9.60 & 6.16 & 4.11 & 52.14 & $7.31^{\mathrm{a}}$ & 1.15 & $48.8^{\mathrm{c}}$ \\
30\%CDP (T1) & 13.20 & 7.34 & 3.89 & 43.00 & $10.15^{\mathrm{b}}$ & 0.94 & $40.4^{\mathrm{b}}$ \\
30\%CDP+EC (T2) & 12.40 & 6.78 & 3.99 & 63.56 & $7.60^{\mathrm{a}}$ & 1.01 & $47.0^{\mathrm{c}}$ \\
50\%CDP (T3) & 14.30 & 6.52 & 3.99 & 58.60 & $6.99^{\mathrm{a}}$ & 0.88 & $35.8^{\mathrm{a}}$ \\
50\%CDP+EC (T4) & 15.10 & 6.94 & 4.42 & 47.30 & $12.06^{\mathrm{c}}$ & 0.91 & $43.7^{\mathrm{b}}$ \\
SEM & 3.87 & 0.35 & 0.09 & 0.71 & 0.73 & 0.37 & 0.46 \\
P value & 0.33 & 0.89 & 0.44 & 0.11 & 0.05 & 0.14 & 0.12 \\
\hline
\end{tabular}

a, b, c Means on the same column having different letters differ significantly. 
Abdelrahman, Sami, Suliman \& Abudabos

Table 7. The levels of blood serum metabolites at the end of the feeding trial

\begin{tabular}{lccccccc}
\hline Treatment & $\begin{array}{c}\text { Glucose } \\
\text { mg/dl }\end{array}$ & $\begin{array}{c}\text { Total protein } \\
\text { g/dl }\end{array}$ & $\begin{array}{c}\text { Albumin } \\
\text { g/dl }\end{array}$ & $\begin{array}{c}\text { Cholesterols } \\
\text { mg/dl }\end{array}$ & $\begin{array}{c}\text { HDL } \\
\text { g/dl }\end{array}$ & $\begin{array}{c}\text { Creatinine } \\
\text { mg/dl }\end{array}$ & $\begin{array}{c}\text { Urea-N } \\
\text { mg/dl }\end{array}$ \\
\hline Control & $80.00^{\mathrm{a}}$ & 6.80 & 3.76 & $47.80^{\mathrm{a}}$ & 7.20 & $1.17^{\mathrm{b}}$ & 50.30 \\
$30 \%$ CDP (T1) & $115.00^{\mathrm{b}}$ & 6.90 & 5.02 & $63.60^{\mathrm{b}}$ & 8.07 & $1.04^{\mathrm{a}}$ & 58.90 \\
$30 \%$ CDP+EC (T2) & $156.00^{\mathrm{c}}$ & 6.10 & 4.06 & $47.00^{\mathrm{a}}$ & 10.88 & $0.95^{\mathrm{a}}$ & 53.60 \\
$50 \%$ CDP (T3) & $112.00^{\mathrm{b}}$ & 5.12 & 4.39 & $87.10^{\mathrm{c}}$ & 9.57 & $0.92^{\mathrm{a}}$ & 48.60 \\
$50 \%$ CDP+EC (T4) & $132.30^{\mathrm{b}}$ & 7.34 & 3.89 & $52.10^{\mathrm{a}}$ & 10.15 & $0.94^{\mathrm{a}}$ & 40.60 \\
SEM & 8.80 & 0.32 & 0.16 & 5.99 & 0.91 & 0.03 & 0.03 \\
P value & 0.04 & 0.23 & 0.09 & 0.05 & 0.73 & 0.01 & 0.46 \\
\hline
\end{tabular}

a, b, c Means on the same column having different letters differ significantly.

Table 8. Effect of crushed date pits (CDP) with or without enzyme cocktail (EC) replacement levels instead of barley on the economic efficiency of growing Naimi lambs

\begin{tabular}{lccccc}
\hline Parameter & Control & 30\% CDP (T1) & 30\% CDP + EC (T2) & 50\%CDP (T3) & 50\%CDP + EC (T4) \\
\hline Total body weight gain, Kg & 19.62 & 17.82 & 18.68 & 16.10 & 18.33 \\
Total feed intake, Kg/lamb & 111.50 & 112.31 & 112.35 & 112.22 & 111.66 \\
Price/ Kg feed, SAR & 0.95 & 0.83 & 0.85 & 0.74 & 0.76 \\
Total feed cost, SAR & 103.70 & 93.22 & 95.50 & 83.04 & 84.86 \\
Total body weight gain & 294.30 & 267.30 & 280.20 & 241.50 & 274.95 \\
price, SAR* & & & & & 4.11 \\
Feed cost/ Kg body gain, & 5.29 & 5.23 & 5.11 & 5.16 & 190.09 \\
SAR & 190.60 & 174.08 & 184.70 & 158.64 & 99.73 \\
Net revenue & 100.00 & 91.30 & 96.90 & 83.23 & \\
Relative Economical & & & & & \\
efficiency, $\%$ )
\end{tabular}

${ }^{*}$ Cost of $1 \mathrm{~kg}$ body weight gain is 15 Saudi Riyal (SAR), Cost of $1 \mathrm{~kg}$ CDP is $0.30 \mathrm{SAR}$, Cost of $1 \mathrm{Kg}$ enzyme is 20 SAR,

1 USA $\$=3.75$ SAR.

Economic efficiency: The average total feed cost for the whole fattening period for the control, T1, T2, T3 and T4 were 103.70, 93.22, 95.50, 83.04 and 84.86 SAR (Saudi Riyal) SAR, respectively as presented in Table 8 . The total weight gain price, $15 \mathrm{SAR} / 1 \mathrm{Kg}$ gain, for the control, T1, T2, T3 and T4 were 294.3, 267.3, 280.2, 241.5 and 274.95 SAR, respectively. The relative economic efficiency for the lambs from T1, T2 and T3 is low compared with the control, but for lambs from T4 is almost the same $(99.73 \%)$ ). It is clear that CDP can be used with EC to replace $50 \%$ of barley in lambs' rations with almost the same economic efficiency.

\section{DISCUSSION}

It is very clear that the growth performance of lambs from T4, $50 \%$ CDP replacement with EC, was not differing from the control group which agreed with findings reported by AlShanti et al. (2013). Many researchers obtained very promising results regarding using date pits with different levels to replace barley in the rations of growing lambs, kids and calves (Milad et al., 2014; Shawket et al., 2010). It has to be noticed that date pits contain high Neutral Detergent Fiber (NDF) which reported to be more than $60 \%$ (Sallam et al., 2007) that play an important role as an energy source. So, addition of fibrolytic enzymes may affect the digestion in the rumen and explain our findings. According to literature, addition of fibrolytic enzyme increase rate (Beauchemin et al., 2003) or extent (Krueger et al., 2008) of fiber hydrolysis and digestion and can reduce in fiber concentration. This leads to influence the acetate to propionate ratio in the rumen fluid and consequently type of energy available for animal productivity.

As a general trend, all the blood serum metabolites that measured were fallen within the normal reference range values according to Kaneko et al. (2008) and many other researchers. The findings for the total protein and albumin that were not affected by treatments completely agreed with Al-Shanti et al. (2013), but disagreed for the other metabolites. The disagreement may be resulted from adding the enzyme cocktail to the CDP in the total mixed rations. For example, adding the enzyme increase the glucose levels in the blood serum of lambs fed 30\% and 50\% CDP when compared with the control. Enzyme cocktail may affect the fiber fermentation pattern in the rumen and reticulum and increase the production of volatile fatty acids especially propionic acid. Furthermore, the opposite trend was reported for the cholesterol level in which significantly lower values for lambs fed 30 and 50\% CDP with EC when compared with the ones without EC. 
In conclusion, for growing lambs, crushed date pits can be used with enzyme cocktail to replace $50 \%$ of barley in growing lambs diets without any negative effect on their growth performance and with almost the same economic efficiency. Dates byproducts could be used efficiently in the total mixed ration of growing lambs especially when adding fibrolytic enzyme cocktail.

Acknowledgment: Great appreciation goes to King AbdulAziz City for Science and Technology (KACST) for its funding of this study through the research project number LGP-32-15.

\section{REFERENCES}

Al-Dobaib, S.N., M.A. Mehaia and M.H. Khalil. 2009. Effect of feeding discarded dates on milk yield and composition of Aradi goats. Small Rumin. Res. 81:167-170.

Alhomidy, S.N., S. Basmaeil, A.N. Al-Owaimer, A.M. Elwaziry and M. Koohmaraie. 2011. Effect of feeding different amounts of discarded dates on growth and efficiency of digestion in sheep. Aust. J. Basic Appl. Sci. 5:636-640.

Al-Shanti, H.A., A.M. Kholif, K.J. Al-Shakhrit, M.F. AlBanna and I.E. Abu-Showayb. 2013. Use of crushed date seeds in feeding growing Assaf lambs. Egypt. J. Sheep Goat Sci. 8:65-73.

A.O.A.C. 1996. Official Methods of Analysis, $16^{\text {th }}$ Ed. Association of Official Analytical Chemists, Washington, DC, USA.

Arhab, R., D. Macheboeuf, M. Doreau and H. Bousseoua. 2006. Nutritive value of date palm leaves and Aristida Pungens estimated by chemical, in vitro and in situ methods. Trop. Subtrop. Agroecosys. 6:167-175.

Beauchemin, K.A., D. Colombatto, D.P. Morgavi and W.Z. Yang. 2003. Use of exogenous fibrolytic enzymes to improve feed utilization by ruminants. J. Anim. Sci. 81:E37-47.

FAO. 2009. Food and agriculture organization of the United Nations. Statistics: FAOSTAT Agriculture.

Geelen, E.F. and A. Udo De Haes. 1964. Investigations of incorporating sun-dried dates in a livestock feed. Report to Ministry of Industry of the Libyan Government. Central Technical Institute (TNO), Netherlands.

Habib, H.M. and W.H. Ibrahim. 2011. Effect of date seeds on oxidative damage and antioxidant status in vivo. J. Sci. Food Agric. 91:1674-1679.

Jumah, H.F., I.I. Al-Azawi and S.A. Al-Hashimi. 1973. Some nutritional aspects of feeding ground date pits for broilers. Mesopotamia J. Agric. 8:139-145.

Jumah, K.H., J.E. Alkass and A.H. Al-Haboby. 1983. Effect of feeding date stones on sperm output in Hamdani rams: a preliminary study (Iraq). Ind. J. Anim. Sci. 53:719-721.
Kaneko, J.J., J.W. Harvey and M.L. Bruse. 2008. Clinical Biochenestry of Domestic Animals, $6^{\text {th }}$ Ed. Elsevier Academic press, Amsterdam, Netherland.

Krueger, N.A. and A.T. Adesogan. 2006. Effect of multi enzyme cocktails on the digestion and fermentation of bahiagrass hay. J. Dairy Sci. 89:254 (abstract 283).

Krueger, N.A., A.T. Adesogan, C.R. Staples, W.K. Krueger, S.C. Kim and R.C. Littell. 2008. Effect of mode of applying fibrolytic enzymes or ammonia to bermudagrass hay on feed intake, digestion kinetics and growth of beef steers. J. Anim. Sci. 86:882-889.

Mahgoub, O., I.T. Kadim, M.H. Al-Busaidi, K. Annamalai and N.M. Al-Saqri. 2007. Effects of feeding ensiled date palm fronds and a byproduct concentrate on performance and meat quality of Omani sheep. Anim. Feed Sci. Tech. 135:210-221.

Mahgoub, O., I.T. Kadim, M.H. Tageldin, W.S. Al-Marzooqi, S.Q. Khalaf and A. A. Ali. 2008. Clinical profile of sheep fed non-conventional feeds containing phenols and condensed tannins. Small Rumin. Res. 78:115-122.

McAllister, T.A., A.N. Hristov, K.A. Beauchemin, L.M. Rode and K.J. Cheng. 2001. Enzymes in ruminant diets. In: M.R. Bedford and G.G. Partridge (eds.), Enzymes in Farm Animal Nutrition. CAB Publishing, Oxon; pp.273297.

Milad, I.S., A.M. Zahhaf and I.A. Azaga. 2014. The effect of replacing barley with ground date seeds on the performance of growing ale goats. Iranian J. Appl. Anim. Sci. 4:197-200.

Morgavi, D.P., K.A. Beauchemin, V.L. Nsereko, L.M. Rode, A.D. Iwaasa and W. Z. Yang. 2000. Effect of enzyme feed additives and method of application on in vitro feed digestibility. J. Dairy Sci. 83:1310-1321.

NRC. 1985. Nutrient Requirements of Sheep, $6^{\text {th }}$ Ed. Natl. Acad. Press, Washington.

Rode, L.M., W.Z. Yang and K.A. Beauchemin. 1999. Fibrolytic enzyme supplements for dairy cows in early lactation. J. Dairy Sci. 82:2121-2126.

Sallam, S.M.A., M.E.A. Nasser, A.M. EL Waziry, I.C.S. Bueno and A.L. Abdalla. 2007. Use of an in vitro rumen gas production technique to evaluate some ruminant feedstuffs. J. Appl. Sci. Res. 3:34-41.

SAS Institute Inc. 2009. SAS Users Guide: Statistics. Version 9.1.3. SAS Institute, Cary, NC, USA.

Shawket, S.M., M.H. Ahmed and M.A. Ibrahim. 2010. Impact of feeding Atriplex halimus and Acacia saligna with different sources of energy on lamb performance. Egypt. J. Sheep Goat Sci. 5:191-208.

Ziaei, N. 2010. The effect of dietary Alhagi (Camel grass) ensiled with different levels of low quality date palm on apparent nutrient digestion coefficients in Kermani sheep. Res. J. Biol. Sci. 5:314-317. 